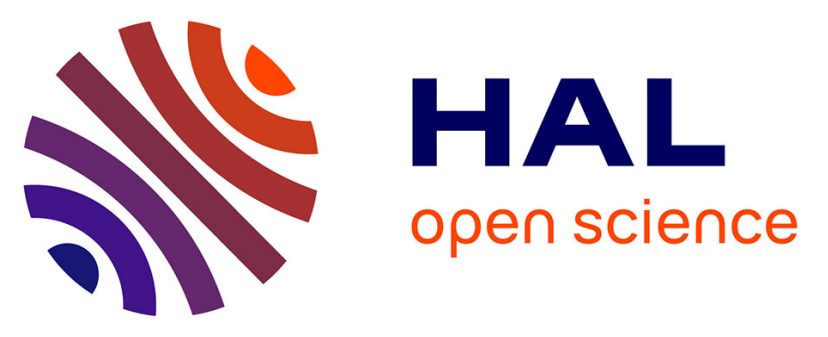

\title{
Dysregulation of GSK3 $\beta$-Target Proteins in Skin Fibroblasts of Myotonic Dystrophy Type 1 (DM1) Patients
}

Valentina Grande, Denisa Hathazi, Emily O'connor, Theo Marteau, Ulrike Schara-Schmidt, Andreas Hentschel, Genevieve Gourdon, Nikoletta Nikolenko, Hanns Lochmüller, Andreas Roos

\section{To cite this version:}

Valentina Grande, Denisa Hathazi, Emily O'connor, Theo Marteau, Ulrike Schara-Schmidt, et al.. Dysregulation of GSK3 $\beta$-Target Proteins in Skin Fibroblasts of Myotonic Dystrophy Type 1 (DM1) Patients. Journal of Neuromuscular Diseases, 2021, 8, pp.603 - 619. 10.3233/jnd-200558 . hal03463068

\section{HAL Id: hal-03463068 https://hal.sorbonne-universite.fr/hal-03463068}

Submitted on 2 Dec 2021

HAL is a multi-disciplinary open access archive for the deposit and dissemination of scientific research documents, whether they are published or not. The documents may come from teaching and research institutions in France or abroad, or from public or private research centers.
L'archive ouverte pluridisciplinaire HAL, est destinée au dépôt et à la diffusion de documents scientifiques de niveau recherche, publiés ou non, émanant des établissements d'enseignement et de recherche français ou étrangers, des laboratoires publics ou privés. 

in Skin Fibroblasts of Myotonic Dystrophy Type 1 (DM1) Patients

Valentina Grande $^{\mathrm{a}}$, Denisa Hathazi ${ }^{\mathrm{b}, \mathrm{c}}$, Emily O'Connor $^{\mathrm{d}}$, Theo Marteau ${ }^{\mathrm{a}}$, Ulrike Schara-Schmidt ${ }^{\mathrm{a}}$, Andreas Hentschel $^{\mathrm{b}}$, Genevieve Gourdon ${ }^{\mathrm{e}}$, Nikoletta Nikolenko ${ }^{\mathrm{f}}$, Hanns Lochmüller ${ }^{\mathrm{d}, \mathrm{g}, \mathrm{h}, \mathrm{i}}$ and Andreas Roos ${ }^{\mathrm{a}, \mathrm{d}, *}$

${ }^{a}$ Department of Neuropediatrics, University Hospital Essen, Duisburg-Essen University, Germany

${ }^{\mathrm{b}}$ Leibniz-Institut für Analytische Wissenschaften -ISAS- e.V., Dortmund, Germany

${ }^{\mathrm{c}}$ Department of Clinical Neurosciences, University of Cambridge School of Clinical Medicine, Cambridge, UK

${ }^{\mathrm{d}}$ Children's Hospital of Eastern Ontario Research Institute, University of Ottawa, Ottawa, ON, Canada

${ }^{\mathrm{e}}$ Inserm UMR 974, Sorbonne Université, Centre de Recherche en Myologie, Association Institut de Myologie, Paris, France

${ }^{\mathrm{f}}$ National Hospital for Neurology and Neurosurgery, Queen Square, University College London Hospitals NHS Foundation Trust, London, UK

${ }^{\mathrm{g}}$ Division of Neurology, Department of Medicine, The Ottawa Hospital, Ottawa, ON, Canada

${ }^{\mathrm{f}}$ Department of Neuropediatrics and Muscle Disorders, Medical Center - University of Freiburg, Faculty of Medicine, Freiburg, Germany

${ }^{\mathrm{i} C e n t r o ~ N a c i o n a l ~ d e ~ A n a ́ l i s i s G e n o ́ m i c o, ~ C e n t e r ~ f o r ~ G e n o m i c ~ R e g u l a t i o n ~(C N A G-C R G), ~ B a r c e l o n a ~ I n s t i t u t e ~ o f ~}$ Science and Technology (BIST), Barcelona, Catalonia, Spain

Pre-press 1 March 2021

\begin{abstract}
Myotonic dystrophy type 1 (DM1) is the most common monogenetic muscular disorder of adulthood. This multisystemic disease is caused by CTG repeat expansion in the $3^{\prime}$-untranslated region of the DM1 protein kinase gene called $D M P K$. DMPK encodes a myosin kinase expressed in skeletal muscle cells and other cellular populations such as smooth muscle cells, neurons and fibroblasts. The resultant expanded (CUG)n RNA transcripts sequester RNA binding factors leading to ubiquitous and persistent splicing deregulation. The accumulation of mutant CUG repeats is linked to increased activity of glycogen synthase kinase 3 beta (GSK3 $\beta$ ), a highly conserved and ubiquitous serine/threonine kinase with functions in pathways regulating inflammation, metabolism, oncogenesis, neurogenesis and myogenesis. As GSK3 $\beta$-inhibition ameliorates defects in myogenesis, muscle strength and myotonia in a DM1 mouse model, this kinase represents a key player of DM1 pathobiochemistry and constitutes a promising therapeutic target. To better characterise DM1 patients, and monitor treatment responses, we aimed to define a set of robust disease and severity markers linked to GSK3 3 by unbiased proteomic profiling utilizing fibroblasts derived from DM1 patients with low (80-150) and high (2600-3600) CTG-repeats. Apart from GSK3 $\beta$ increase, we identified dysregulation of nine proteins (CAPN1, CTNNB1, CTPS1, DNMT1, HDAC2, HNRNPH3, MAP2K2, NR3C1, VDAC2) modulated by GSK3 $\beta$. In silico-based expression studies confirmed expression in neuronal and skeletal muscle cells and revealed a relatively elevated abundance in fibroblasts. The potential impact of each marker in the myopathology of DM1 is discussed based on respective function to inform potential uses as severity markers or for monitoring GSK3 $\beta$ inhibitor treatment responses.
\end{abstract}

Keywords: GSK3 $\beta$, fibroblast proteomics, CTPS1, CAPN1, HDAC2, CTNNB1

*Correspondence to: Andreas Roos, Tel.: +49 201723 6570;

E-mail: andreas-roos@uk-essen.de. 


\section{INTRODUCTION}

Myotonic dystrophy type 1 (DM1; MIM: 160900) is the most common monogenetic muscular disorder of adulthood with an estimated worldwide prevalence of $5 / 100,000$, ranging from 0.5 in Taiwan up to $18.1 / 100,000$ in Croatia [1]. In addition, DM1is highly prevalent in Canada (Saguenay-Lac-SaintJean) where its carrier rate reaches $1 / 550[2,3]$. The disease is characterised by progressive muscle atrophy and weakness, often combined with myotonia, fatigue, respiratory insufficiency, and speech and swallowing difficulties [4, 5]. DM1 represents a multisystemic disorder and affects multiple organs including the central nervous system, heart, eye, skin, gastrointestinal and reproductive tracts, as well as the endocrine and immune systems [5]. Traditionally, DM1 is categorized according to phenotype and age of onset. However, this classification into congenital, juvenile, childhood, adult and late onset is complicated by significant intrafamilial and interfamilial variability $[5,6]$.

DM1 is an autosomal dominant disorder, caused by a CTG repeat expansion [(CTG)n] in the $3^{\prime}$ untranslated region of the DM1 protein kinase gene (DMPK). DMPK is located at position $19 \mathrm{q} 13.32$ and encodes a myosin kinase expressed in skeletal muscle [7]. Expanded alleles display microsatellite instability towards expansion in germline cells (causing genetic anticipation) and somatic cells (contributing to disease progression and phenotype variability [811]). The resultant expanded (CUG)n RNA transcripts cause the DM1 phenotype by sequestering RNA binding factors and leading to ubiquitous and persistent splicing deregulation [5, 12-17]. This toxic (CUG)n RNA effect is mediated by gain of function of combined CUGBPElav-like family member 1 (CELF1) and loss of function of muscleblind like splicing regulator (MBNL) due to clustering of both proteins [15-17]. Several aberrant splicing events have been linked to muscular $[15,16,18-21]$, cardiac $[15,20,22,23]$, neurocognitive $[24,25]$ and endocrine $[15,16,26-28]$ features of DM1.

Glycogen synthase kinase 3 beta (GSK3 $\beta$ ) activity is significantly increased in the skeletal muscles of DM1 patients [29]. This increase in GSK3 $\beta$ activity is linked to the accumulation of mutant CUG repeats and, by promoting the phosphorylation of cyclin D3 at T283, leading to degradation and resultant in muscle weakness. GSK $3 \beta$ is a highly conserved and ubiquitous serine/threonine kinase with an important pleiotropic role in pathways regulating inflammation, metabolism, oncogenesis, neurogenesis and myogenesis [29-34]. Pharmacological inhibition of GSK3 $\beta$ ameliorates defects in myogenesis, muscle strength and myotonia in DM1 mice (HSA ${ }^{\mathrm{LR}}$ ) [29] further supporting the emergence of GSK3 $\beta$ as a novel and promising therapeutic target for DM1 [35]. To better characterise DM1 patients, and monitor treatment responses, it will be necessary to define a set of robust disease and severity markers.

\section{PATIENTS, MATERIAL AND METHODS}

In this study, we aimed to identify DM1 protein markers reflecting activation of pathways, such as GSK3 $\beta$ overactivation, in patient-derived fibroblasts, a suitable cell model to study the molecular etiology of neuromuscular diseases [36]. Proteomic profiling was performed on fibroblasts derived from DM1patients with a mild/late onset [(CTG) 80-150] and a severe/congenital [(CTG) 2600-3600] DM1 phenotype. Obtained data were filtered for dysregulated proteins that are known to be modulated by GSK3 $\beta$ or involved in GSK3 $\beta$-dependent processes.

\section{Ethical considerations}

This study has been ethically approved as a substudy as part of OPTIMISTIC (reference: NRES Committee North East - Sunderland 13.NE.0342) and PHENODM1 (reference: NRES Committee North East - Tyne \& Wear South 15.NE.0178). Patients were consented and recruited at Newcastle upon Tyne NHS Foundation Trust and all procedures leading to these results complied with the Good Clinical Practices and the Declaration of Helsinki.For skin biopsies studies, informed consent was obtained from all patients.

\section{Fibroblasts and cell culture}

Fibroblasts were isolated from fresh donor skin biopsies following standardised EuroBioBank protocols (www.eurobiobank.org/biobanking-sops): biopsies were washed with sterile phosphate-buffered saline (PBS) and digested at $37^{\circ} \mathrm{C}$ for 15 minutes with $2.5 \%$ trypsin (Thermo Fisher Scientific) and a further 90 minutes with $0.5 \%$ collagenase (Type IV, Sigma-Aldrich). Fibroblasts were proliferated in Ham's F-10-Complete Medium (Thermo Fisher Scientific) supplemented with $20 \%$ foetal bovine serum (FBS, SeraLab - Bioreclamation IVT), $2 \%$ penicillin-streptomycin (Thermo Fisher Scientific), 1\% 
Table 1

Clinical findings for the six DM1 patients who provided fibroblasts for the proteomic profiling study. MIRS: Muscular impairment rating scale. Repeat expansions refer to DNA extracted from fibroblasts

\begin{tabular}{|c|c|c|c|c|c|}
\hline $\begin{array}{l}\text { Patient/ } \\
\text { sample }\end{array}$ & $\begin{array}{l}\text { CTG- } \\
\text { repeats }\end{array}$ & $\begin{array}{c}\text { Age at } \\
\text { disease onset } \\
\text { [years] }\end{array}$ & $\begin{array}{c}\text { Age at time } \\
\text { of study } \\
\text { (skin biopsy) }\end{array}$ & $\begin{array}{l}\text { Main DM symptoms } \\
\text { (in addition to muscle weakness) }\end{array}$ & MIRS \\
\hline 1 & 84 & 34 & 50 & Conduction defect, excessive daytime sleepiness & III \\
\hline 2 & 94 & 45 & 55 & Excessive day-time sleepiness & II \\
\hline 3 & 140 & 49 & 58 & Conduction defect, cataracts & IV \\
\hline 4 & 2431 & 9 & 43 & $\begin{array}{l}\text { Conduction defect, cataracts, breathing difficulties, } \\
\text { excessive day-time sleepiness }\end{array}$ & IV \\
\hline 5 & 2683 & 16 & 35 & $\begin{array}{l}\text { Excessive day-time sleepiness, } \\
\text { breathing difficulties }\end{array}$ & III \\
\hline 6 & 3187 & 25 & 60 & $\begin{array}{l}\text { Excessive day-time sleepiness, conduction defect, } \\
\text { breathing difficulties, cataracts }\end{array}$ & $\mathrm{V}$ \\
\hline
\end{tabular}

GlutaMAX $^{\mathrm{TM}}$ (Thermo Fisher Scientific) and 1\% fungizone (Thermo Fisher Scientific). Once fibroblast cells attained sufficient confluency, they were frozen and stored long-term in liquid nitrogen. For further experiments including proteomic profiling, cells were cultured as described above until a confluence of $70 \%$, harvested by scraping from culture flasks, washed twice with ice-cold PBS and cell pellets were snap-frozen in liquid nitrogen and stored at $-80^{\circ} \mathrm{C}$ until further processing.

In total 12 fibroblast samples were included in our proteomic study: 3 DM1 fibroblast lines from patients with early onset, severe disease and CTG-repeat expansions of more than 2000 (patients 4-6:2431, 2683 and 3187 CTG-repeats, respectively), 3 DM1 fibroblast lines from patients with late onset, mild disease and CTG-repeat expansions between 80 and 150 CTG-repeats (patients 1-3:84, 94 and 140 CTGrepeats, respectively), and a total of 6 sex- and agematched controls (three controls per patient-group). DM1-patient derived cell lines were obtained from the "MRC Centre Neuromuscular Biobank" (Newcastle upon Tyne, UK) [37]. All patients were adults when the skin biopsies were taken. Clinical data for the individual patients are listed in Table 1 .

\section{Unbiased label-free LC-MS/MS and data analysis}

The following reagents were used for LC-MS/MS: Ammonium hydrogen carbonate $\left(\mathrm{NH}_{4} \mathrm{HCO}_{3}\right)$, anhydrous magnesium chloride $\left(\mathrm{MgCl}_{2}\right)$, guanidine hydrochloride $(\mathrm{GuHCl})$, iodoacetamide (IAA), and urea (Sigma-Aldrich, Steinheim, Germany), tris base (ApplichemBiochemica, Darmstadt, Germany), sodium dodecyl sulfate (SDS) (Carl Roth, Karlsruhe, Germany), dithiothreitol (DTT), EDTA-free protease inhibitor (Complete Mini) tablets (Roche Diagnostics,
Mannheim, Germany), $\mathrm{NaCl}, \mathrm{CaCl}_{2}$ (Merck, Darmstadt, Germany), sequencing grade modified trypsin (Promega, Madison, WI USA), Benzonase ${ }^{\circledR}$ Nuclease (Novagen), a bicinchoninic acid assay (BCA) kit (Thermo Fisher Scientific, Dreieich, Germany). All chemicals for ultra-pure HPLC solvents such as formic acid (FA), trifluoroacetic acid (TFA) and acetonitrile (ACN) were obtained from Biosolve, Valkenswaard, The Netherlands.

\section{Cell lysis, sample clean-up and proteolysis}

Cell pellets were lysed in $100 \mu \mathrm{L}$ of lysis buffer (50 mM Tris- $\mathrm{HCl}$ (pH 7.8), $150 \mathrm{mM} \mathrm{NaCl}, 1 \%$ SDS, and Complete Mini) using a manual glass grinder. Extracts were centrifuged at $6000 \mathrm{~g}$ for $5 \mathrm{~min}$ at $4^{\circ} \mathrm{C}$ to separate cell debris from the protein lysate and protein concentration was determined by BCA assay (according to the manufacturer's protocol). Cysteines were reduced via the addition of $10 \mathrm{mM}$ DTT followed by an immediate incubation at $56^{\circ} \mathrm{C}$ for $30 \mathrm{~min}$. Alkylation of free thiol groups with $30 \mathrm{mM}$ IAA was performed at room temperature (RT) in the dark for $30 \mathrm{~min}$.

Sample preparation was performed using filteraided sample preparation (FASP) [38, 39] with some minor changes: $100 \mu \mathrm{g}$ of protein lysate was diluted 10 -fold with freshly prepared $8 \mathrm{M}$ urea/ $100 \mathrm{mM}$ Tris$\mathrm{HCl}(\mathrm{pH} 8.5)$ buffer and placed on a PALL microsep centrifugal device ( $30 \mathrm{KDa}$ cut off) and centrifuged at $13,500 \mathrm{~g}$ at RT for $20 \mathrm{~min}$ (all the following centrifugation steps were performed under the same conditions). Three washing steps were carried out with $100 \mu \mathrm{L}$ of $8 \mathrm{M}$ urea/100 mM Tris- $\mathrm{HCl}$ (pH 8.5). For buffer exchange, the device was washed three times with $100 \mu \mathrm{L}$ of $50 \mathrm{mM} \mathrm{NH} \mathrm{HCO}_{3}$ (pH 7.8). The digestion buffer (final volume of $100 \mu \mathrm{L}$ ) composed of trypsin $(1: 25 \mathrm{w} / \mathrm{w}$, protease to substrate), $0.2 \mathrm{M} \mathrm{GuHCl}$ and $2 \mathrm{mM} \mathrm{CaCl}_{2}$ in $50 \mathrm{mM} \mathrm{NH}_{4} \mathrm{HCO}_{3}$ 
( $\mathrm{pH} 7.8$ ), was added to the concentrated proteins and samples incubated at $37^{\circ} \mathrm{C}$ for $14 \mathrm{~h}$. The resulting tryptic peptides were recovered by centrifugation with $50 \mu \mathrm{L}$ of $50 \mathrm{mM} \mathrm{NH}_{4} \mathrm{HCO}_{3}$ followed by $50 \mu \mathrm{L}$ of ultra-pure water. Peptides were acidified $(\mathrm{pH}<3$ by addition of $10 \%$ TFA (v/v)). All digests were quality controlled as described previously [40].

\section{LC-MS/MS analysis}

$1 \mu \mathrm{g}$ of each sample was analyzed using an Ultimate 3000 nano RSLC system coupled to an Orbitrap Fusion Lumos mass spectrometer (both Thermo Scientific) in a randomized order to minimize systematic errors. Peptides were preconcentrated on a $100 \mu \mathrm{m}$ $\times 2 \mathrm{~cm} \mathrm{C} 18$ trapping column for $10 \mathrm{~min}$ using 0.1 $\%$ TFA (v/v) at a flow rate of $20 \mu \mathrm{L} / \mathrm{min}$ followed by separation on a $75 \mu \mathrm{m} \times 50 \mathrm{~cm} \mathrm{C18} \mathrm{main} \mathrm{column}$ (both Pepmap, Thermo Scientific) with a 95 min LC gradient ranging from $3-35 \%$ of $84 \%$ ACN, 0.1 $\%$ FA (v/v) at a flow rate of $250 \mathrm{~nL} / \mathrm{min}$. MS survey scans were acquired in the Orbitrap from 300 to $1500 \mathrm{~m} / \mathrm{z}$ at a resolution of 120,000 using the polysiloxane ion at $\mathrm{m} / \mathrm{z} 445.12002$ as lock mass [41], an automatic gain control target value of $2.0 \times 10^{5}$ and maximum injection times of $50 \mathrm{~ms}$. TopSmost intense signals were selected for fragmentation by higher-energy collisional dissociation with an energy of $30 \%$ and MS/MS spectra were acquired in the Iontrap using an automatic gain control target value of $2.0 \times 10^{3}$ ions, a maximum injection time of $300 \mathrm{~ms}$, a dynamic exclusion of $15 \mathrm{~s}$ and an isolation window of $1.2(\mathrm{~m} / \mathrm{z})$.

\section{Label free data analysis}

Data analysis of the acquired label free MS data was performed using the Progenesis LC-MS software from Nonlinear Dynamics (Newcastle upon Tyne, U.K.). Raw MS data was aligned by Progenesis, which automatically selected one of the LC-MS files as reference. After automatic peak picking, only features within retention time and $\mathrm{m} / \mathrm{z}$ windows from 0-95 $\mathrm{min}$ and $300-1500 \mathrm{~m} / \mathrm{z}$, with charge states +2 , +3 , and +4 were considered for peptide statistics and analysis of variance (ANOVA) and MS/MS spectra were exported as peak lists. Peak lists were searched against a concatenated target/decoy version of the human Uniprot database (downloaded on 22.07.2015 containing 20273 target sequences) using Mascot 2.4 (Matrix Science, Boston, MA, USA), MS-GF + (beta,v10282), X!Tandem (X!Tandem Vengeance, 2015.12.15.2) and MyriMatch (2.2.140) with the help of searchGUI 3.2.5 [42]. Trypsin was selected as the enzyme, with a maximum of two missed cleavages, carbamidomethylation of cysteine was set as fixed and oxidation of methionine was selected as variable modification. MS and MS/MS tolerances were set to 10 p.p.m and $0.5 \mathrm{Da}$, respectively.

To obtain a peptide-spectrum match and to maximize the number of identified peptides and proteins at a given quality, we used PeptideShaker software 1.4.0 (http://code.google.com/p/peptide-shaker/) [43]. Combined search results were filtered at a false discovery rate of $1 \%$ on the peptide and protein level and exported using the PeptideShaker features that allow direct re-import of the quality-controlled data into Progenesis. Peptide sequences containing oxidized methionine were excluded from further analysis. Only proteins quantified with unique peptides were exported. For each protein, average of the normalized abundances obtained from Progenesis was calculated to determine the ratios between the patient and control cells. Only proteins which were $(i)$ commonly quantified in all the replicates with (ii) a minimum of one unique peptide, (iii) an ANOVA $p$-value of $\leq 0.05$ (Progenesis) and (iv) an average ratio $\log _{2} \leq 5.8$ or $\geq-0.73$ for the low repeats (comparison 1) and an average ratio $\log _{2} \leq 5.6$ or $\geq-2.3$ for the high repeats (comparison 2) were considered as significantly regulated.

"STRING" (Search Tool for the Retrieval of Interacting Genes/Proteins; www.string-db.org) enables the delineation of direct and functionally related protein-protein interactions. Thus, to identify functional interdependences of proteins with altered abundances in diseased cells and tissues, we applied this in silico tool to decipher proteins interacting with the ten marker proteins identified by our proteomic profiling of DM1-patient derived skin fibroblasts.

The Genotype-Tissue Expression (GTEx; www. gtexportal.org) project, representing a comprehensive public resource to study tissue-specific gene expression, was used to address expression of GSK3 $\beta$ and identified markers in DM1 vulnerable tissues including different brain areas, peripheral nervous system, skeletal and cardiac muscle and skin/cultured fibroblasts. The data used for the analyses described in this manuscript were obtained from the GTEx Portal on 20/05.2020 dbGaP accession number phs000424.vN.pN on 12/10/2012.

Immunohistochemistry on murine muscles

Immunological staining of CAPN1 was performed utilizing cardiac and tibialis anterior muscle derived 
from DMSXL mice (a suitable mouse model of DM1) [44] and wildtype littermates aged two and four months (two animals per group) as described previously [45]. For that purpose, a primary anti-Calpain 1 polyclonal antibody (Invitrogen: \#PA5-86056) was used.

\section{RESULTS}

\section{Expression of GSK3 $\beta$ in fibroblasts derived from patients with DM1}

Proteomic profiles of fibroblasts derived from DM1 patients (early and adult disease onset; Table 1) and respective controls were generated. First, we analysed the proteomic signature for GSK3 $\beta$ within the whole protein extracts obtained from DM1-patient derived fibroblasts. This analysis revealed an increase in GSK3 $\beta$ expression in fibroblasts derived from DM1-patients of both groups; and this effect was more pronounced in cells derived from patients mildly affected by DM1 showing a 2.80-fold increase compared to a 1.62-fold increase in fibroblasts derived from severely affected DM1-patients (severe vs mild $=0.58, \mathrm{p}$-ANOVA $=0.110$, statistically not significant; Table $2 \& 3$; Fig. 1A).

\section{Identification of dysregulated proteins related to GSK3 $\beta$}

Next, we screened these profiles for detection of one of the $\sim 100$ proteins known to be modulated by GSK $3 \beta$ or involved in GSK3 $\beta$-dependent processes, allowing the identification of $25 \mathrm{dysregulated} \mathrm{proteins}$ $[31,30]$ : 9 of these dysregulated proteins were quantified with a statistically significant p-ANOVA $(\leq 0.05)$ in both patient groups (Table $2 \&$ Fig. 1A) and 16 with a statistically significant p-ANOVA $(\leq 0.05)$ in only one of the defined groups (Supplementary Table 1). Out of the nine proteins, four are decreased (DNMT1, VDAC2, HNRNPH3 \& CTNNB1) and five (MAP2K2, HDAC2, NR3C1, CTPS1 \& CAPN1) are increased in both patient groups as compared to controls (Table $2 \&$ Fig. 1A). To further define a disease marker as a marker of severity, the statistical significance of the change in fold-regulation for each protein between mild and severe patient groups was taken into account. This resulted in the definition of three severity markers (Table 2): HDAC2 is 2.42-fold upregulated in cells derived from mild patients, and 4.86-fold increased in severe patients (p-ANOVA 0.005). Similarly, CTPS1 is 1.99 -fold

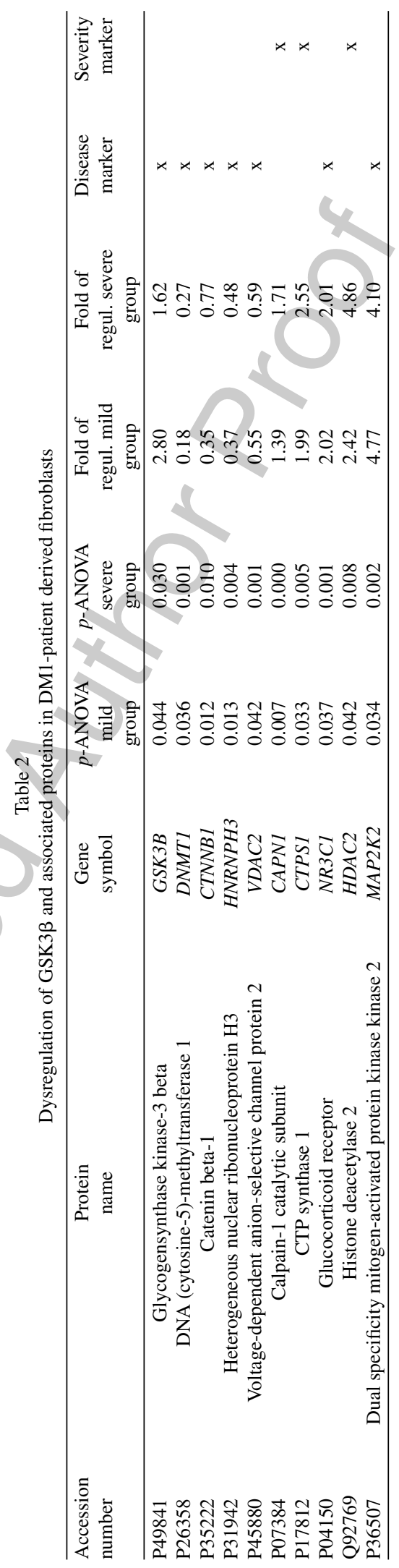


Table 3

Abundance of each GSK3 $\beta$-related protein identified in the proteomics of DM1 patient-derived fibroblasts, as compared to expression levels of GS3K $\beta$

\begin{tabular}{|c|c|c|c|c|c|c|}
\hline \multirow[b]{2}{*}{ Gene symbol } & \multicolumn{3}{|c|}{ Average intensities } & \multicolumn{3}{|c|}{$\begin{array}{l}\text { Ratio of each protein } \\
\text { compared to GS3K } \beta\end{array}$} \\
\hline & Severegroup & Mild group & Controls & Severegroup & Mild group & Controls \\
\hline$G S K 3 B$ & $1.14 \mathrm{E}+06$ & $2.55 \mathrm{E}+06$ & $9.10 \mathrm{E}+05$ & 1.00 & 1.00 & 1.00 \\
\hline DNMT1 & $4.40 \mathrm{E}+05$ & $3.38 \mathrm{E}+05$ & $1.74 \mathrm{E}+06$ & 0.39 & 0.13 & 1,92 \\
\hline$C T N N B 1$ & $4.79 \mathrm{E}+06$ & $5.53 \mathrm{E}+06$ & $1.09 \mathrm{E}+07$ & 4.19 & 2.17 & 12.00 \\
\hline HNRNPH3 & $7.71 \mathrm{E}+06$ & $6.27 E+06$ & $1.65 \mathrm{E}+07$ & 6.75 & 2.46 & 18.15 \\
\hline$V D A C 2$ & $2.15 \mathrm{E}+07$ & $3.02 \mathrm{E}+07$ & $4.53 \mathrm{E}+07$ & 18.84 & 11.87 & 49.81 \\
\hline CAPN1 & $5.82 E+06$ & $7.99 \mathrm{E}+06$ & $4.57 \mathrm{E}+06$ & 5.10 & 3.14 & 5.03 \\
\hline CTPS1 & $2.11 \mathrm{E}+06$ & $2.58 \mathrm{E}+06$ & $1.06 \mathrm{E}+06$ & 1.85 & 1.01 & 1.16 \\
\hline$N R 3 C 1$ & $1.27 \mathrm{E}+06$ & $1.49 \mathrm{E}+06$ & $6.73 E+05$ & 1.11 & 0.58 & 0.74 \\
\hline$H D A C 2$ & $1.59 \mathrm{E}+06$ & $3.70 \mathrm{E}+06$ & $4.03 E+06$ & 1.39 & 1.45 & 4.43 \\
\hline$M A P 2 K 2$ & $7.08 \mathrm{E}+05$ & $5.61 \mathrm{E}+05$ & $1.45 \mathrm{E}+05$ & 0.62 & 0.22 & 0.16 \\
\hline
\end{tabular}

increased in mild patient fibroblasts and 2.55-fold in cells of the severe patient group (p-ANOVA 0.04). Moreover, CAPN1 is 1.39-fold upregulated in cells derived from mild patients, and 1.71-fold increased in severe patients (p-ANOVA 0.002).

\section{Change in expression of dysregulated proteins in relation to GSK3 $\beta$}

To investigate potential stoichiometric changes between GSK3 $\beta$ and the nine substrates dysregulated in DM1-patient derived fibroblasts, we compared the abundance of each protein with GSK3 $\beta$ expression. This comparison revealed decreased ratios for DNMT1, MAP2K2, VDAC2, HDAC2, HNRNPH3 and CTNNB1 in both patient groups compared to controls. For NR3C1 and CTPS1 decreased ratios were observed in the mild group and increased ratios in the severe DM1-patient group. For CAPN1, decreased ratios were identified by comparing control and mild patient group, but ratios remained almost unchanged between the controls and the group of severely affected DM1 patients. All protein intensities and calculated ratios to GSK3 $\beta$ are shown in Fig. 1B and listed in Table 3.

\section{Protein network analysis}

"STRING" protein-network analyses revealed a predicted functional interaction of GSK $3 \beta$, MAP 2K2, CTNNB1, HDAC2, NR3C1, DNMT1\& VDAC2 (Fig. 1C). Expanding the interaction network to include first level interactors of our dysregulated proteins revealed a further predicted interplay of 13 proteins, with the addition of CDH1, FYN, CTNNA1, APC and BCL9 as well as connecting CAPN1 to the functional network (Fig. 1C). Considering second level binding partners, a functional interplay of 18 proteins was delineated, with the addition of AXIN1, FER, AKT1, AKT3 and CTNNBIP1 (Fig. 1C).

In silico tissue expression analysis of dysregulated proteins

To address tissue expression of the identified dysregulated proteins, the GTEx database was used, with a focus on DM1-associated tissues, such as different areas of the central nervous system (amygdala, anterior cingulate cortex, frontal cortex, basal ganglia, cerebellum and cerebellar hemisphere, hippocampus, hypothalamus, substantia nigra and spinal cord), tibial nerve, skeletal and cardiac muscle as well as skin and cultured fibroblasts. Of note, among the different brain areas, all proteins show highest abundance in the cerebellum, including the cerebellar hemisphere. For CAPN1 and MAP2K2 increased abundance was also observed in cortex (Fig. 2). In addition, the nine markers and GSK $3 \beta$ are highly expressed in the tibial nerve, skin and cultured fibroblasts. Compared to the other tissues addressed, moderate abundance in skeletal muscle was observed for GSK3 $\beta$, VDAC2, CAPN1, CTPS1, NR3C1 and MAP2K2 (Fig. 2).

\section{Calpain-1 expression analysis in murine muscle}

To verify our proteomic findings, expression CA$\mathrm{PN} 1$ as a paradigmatic protein was studied in cardiac and tibialis anterior muscle derived from DMSXL mice and wildtype littermates (two and four months of age). For both tissues elevated sarcoplasmic CA PN1 level were observed at two and four months of age, respectively (Fig. 3). 
A

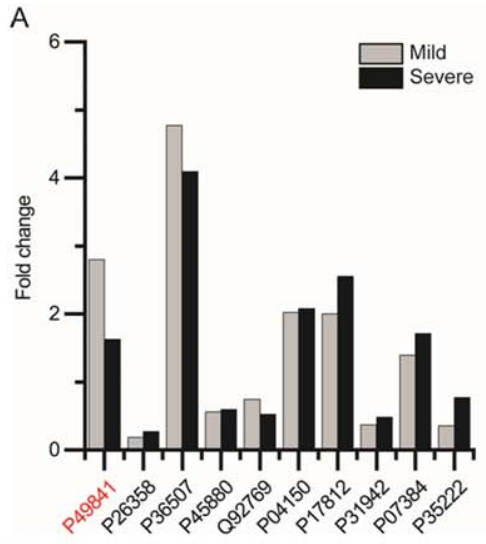

C

STRING-network of GSK3 $\beta$ and nine marker proteins

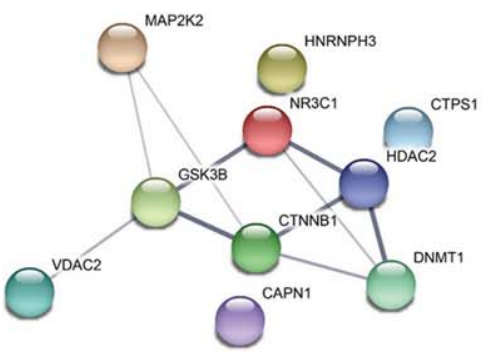

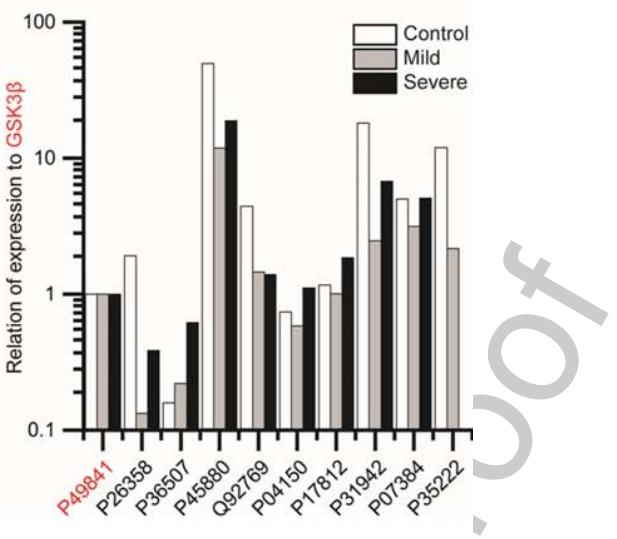

STRING-network of GSK3 $\beta$, the nine marker proteins and first level of interaction partners

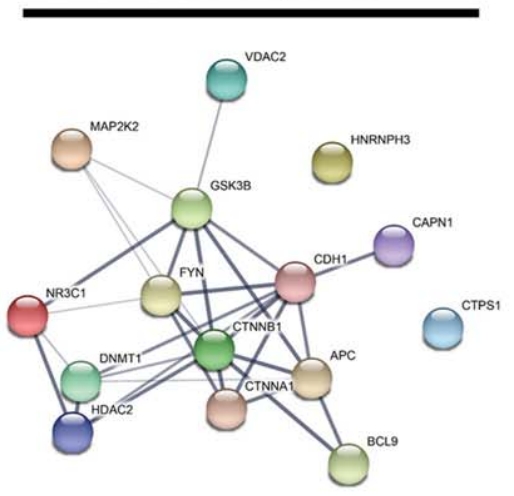

STRING-network of GSK3 $\beta$, the nine marker proteins and first plus second level of interaction partners

Fig. 1. Dysregulation of GSK3 $\beta$ and related proteins identified by unbiased proteomic profiling of DM1-patient derived skin fibroblasts (mildly and severely affected cases). (A) Altered relative expression of GSK3 $\beta$ (P49841; highlighted in red) and nine proteins known to be modulated by its function, thus serving as GSK3 $\beta$-dependent cellular markers of DM1. (B) Changes in abundance of proteins expressed as a ratio with GSK3 $\beta$ expression in fibroblasts derived from mild and severely affected DM1 patients compared to controls. (C) STRING-based protein interaction networks reflecting interaction network of the nine markers identified, including first and second level binding partners. Thickness of the lines between the nodes refers to the confidence of interaction. 

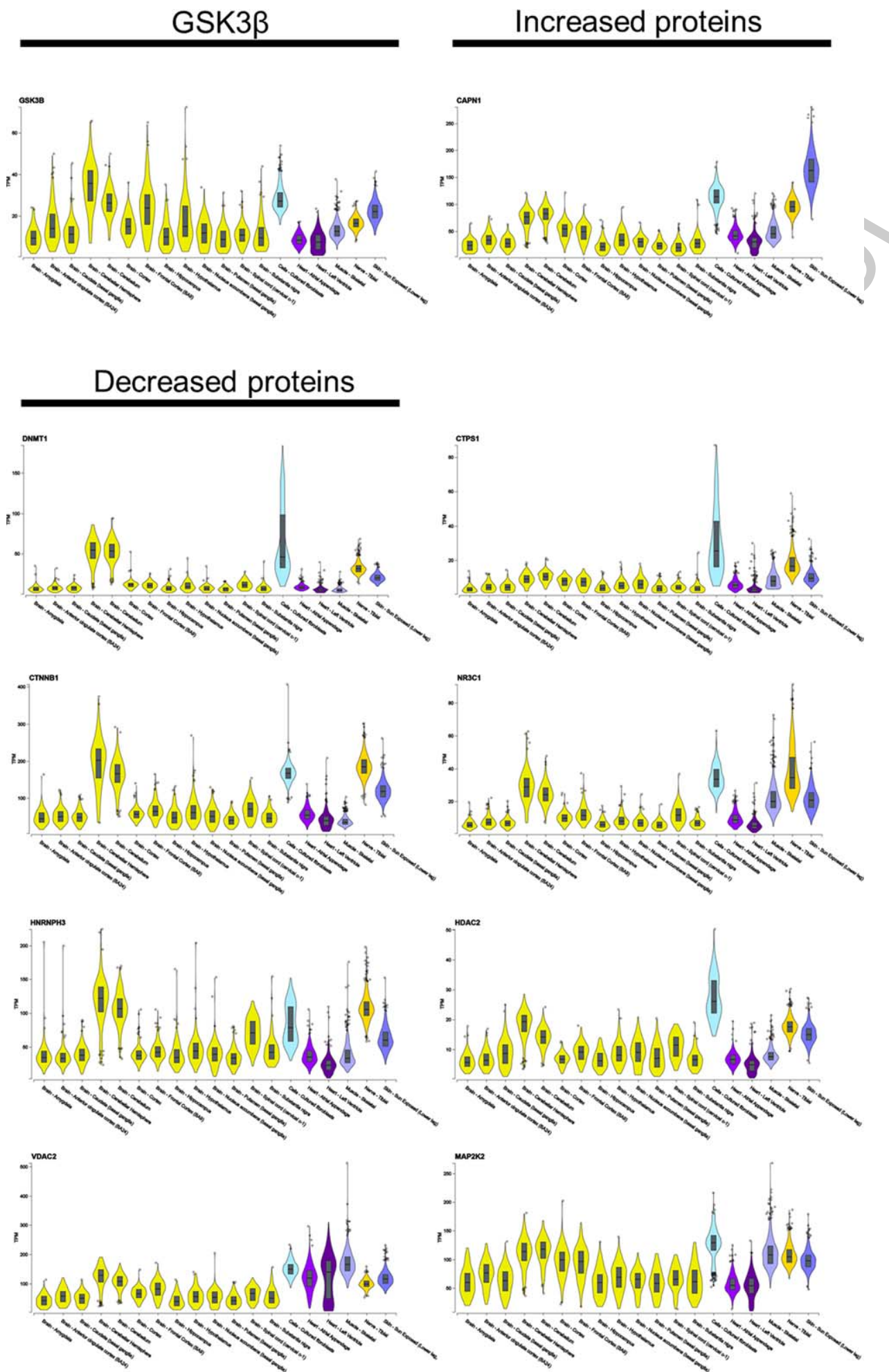

Fig. 2. GTEx-based in silico analysis of tissue expression of GSK3 $\beta$ and the nine associated proteins dysregulated in DM1-patient derived skin fibroblasts. 


\section{DISCUSSION}

Proteomic profiling is a powerful tool for the unbiased identification of proteins contributing to neuromuscular disease pathology in cells and tissues derived from patients $[46,47]$. Fibroblasts are known to be affected in DM1 [48], therefore, we performed LC-MS/MS-based analysis of the protein signature of DM1 patient-derived fibroblasts to identify proteins that may be markers of DM1 presence or severity.

Nearly 100 proteins are proposed to be substrates for GSK3 $\beta$, highlighting the role of this kinase as a fundamental regulator of many cellular processes [31-49]. Given that GSK3 $\beta$-overactivation is found in DM1-patient cells and tissues [29] and that inhibition of this overactivation represents a promising treatment strategy in DM1, we analysed GSK3 $\beta$ abundances in DM1-patient derived cells. This revealed an increase in GSK3 $\beta$ in both mild and severely affected patients. This effect was more pronounced in cells derived from mildly affected DM1-patients, thus in fibroblasts GSK3 $\beta$ protein level does not correlate with CTG-repeat expansion (and the resultant disease-severity classification). However, given that GSK3 $\beta$-overactivation is modulated by post-translational modification, studies of GS3K $\beta$-phosphorylation are needed to draw a conclusion regarding a correlation of GSK3 $\beta$-activation and CTG-repeat expansion/disease severity in DM1fibroblasts.

After filtering out proteomic data for proteins modulated by GSK3 $\beta$, we were left with nine proteins that may be potential markers of DM1 disease or severity. To the best of our knowledge, none of the nine proteins has been described as a DM1 blood biomarker thus far. In silico-based interaction studies suggested a down-stream impact on pathways perturbed in DM1, such as AKT-signalling (AKT1 \& AKT3) [50]. The known ubiquitous expression of the nine cellular markers hints toward a potential overall involvement in DM1-pathophysiology and moreover suggests that further functional studies or pre-clinical intervention concepts can be performed in DM1-patient derived skin fibroblasts. This postulate is further supported by the proven high expression in human cultured skin fibroblasts as exemplified by or in silico-based expression studies. A comparison of their relative abundance with GSK3 $\beta$ levels showed many proteins had expression that varied with severity. This finding suggests a pathophysiological shift of GSK3 $\beta$, and some of its substrates, that may allow their use for tracking progression of disease or response to GSK3 $\beta$ inhibitor therapy. The relevance of each GSK3 $\beta$-related dysregulated protein to DM1 pathophysiology is discussed in subsequent sections:

DNA (cytosine-5)-methyltransferase 1 (DNMT1; decreased in DM1 fibroblasts): DNA (cytosine-5)methyltransferase 1, encoded by the DNMT1 gene, maintains DNA methylation profiles after DNA replication and cell division [51]. Koh and colleagues linked DNMT1 to GSK3 $\beta$ in fibroblasts: they found that when GSK3 $\beta$ is inactivated by phosphorylation, DNMT1 levels are elevated by TGF-beta1 [52]. Recent evidence shows that DNMT11 is required for correct myogenesis, a process impaired in DM1, leading to defective muscle regeneration and to muscle weakness and wasting $[53,54]$. Studies performed in mice with muscle-specific deletion of Dnmt1 revealed a reduced ability of myoblasts to differentiate [55]. Dnmt1-knock down in HT1080 cells, a human fibrosarcoma cell line carrying a copy of a human HPRT minigene inactivated by a $(\mathrm{CAG})_{95}$ repeat tract, destabilizes CAG-repeats, suggesting a fundamental role of Dnmt1 in CAG-repeat instability [56].

DNMT1 expression is more pronounced in "young" human fibroblasts than in passage-aged, and DNMT11-knockdown induces a senescence phenotype in "young" fibroblasts [57].The premature aging in DM1 patients [58] could link to the decreased DN MT1 protein level in DM1 patient derived fibroblasts (Table 1), presumably caused by GSK3 $\beta$ overactivation.

Catenin beta-1 (CTNNB1; decreased in DM1 fibroblasts): is a key component of the canonical Wnt signaling pathway controlling physiological processes like embryonic development, cellular proliferation and differentiation [59]. In the absence of Wnt ligands, $\beta$-catenin is part of a cytoplasmic complex also containing GSK3 $\beta$. This complex facilitates the phosphorylation and ubiquitination of CTN NB1, thus controlling its activation and proteasomemediated degradation. In skeletal muscle, Wnt/ $\beta$ catenin signalling plays a central role in myogenesis, differentiation and myotube hypertrophy [60-62]. Consequently, CTNNB1 is considered a promising target in diseases such as cachexia or muscular dystrophies, characterized by muscle wasting. A chronic overactivation of Wnt pathways was found in skeletal muscles of DMD-patients, driving the activation of TGF $\beta 2$ and thus promoting fibrosis [63]. Of note, exogenous inhibition of the Wnt pathway was shown to reduce fibrosis in dystrophic muscles of the $m d x$ mouse model [64]. In the disease etiology of DM1, CTNNB1-upregulation (via the Wnt signaling 

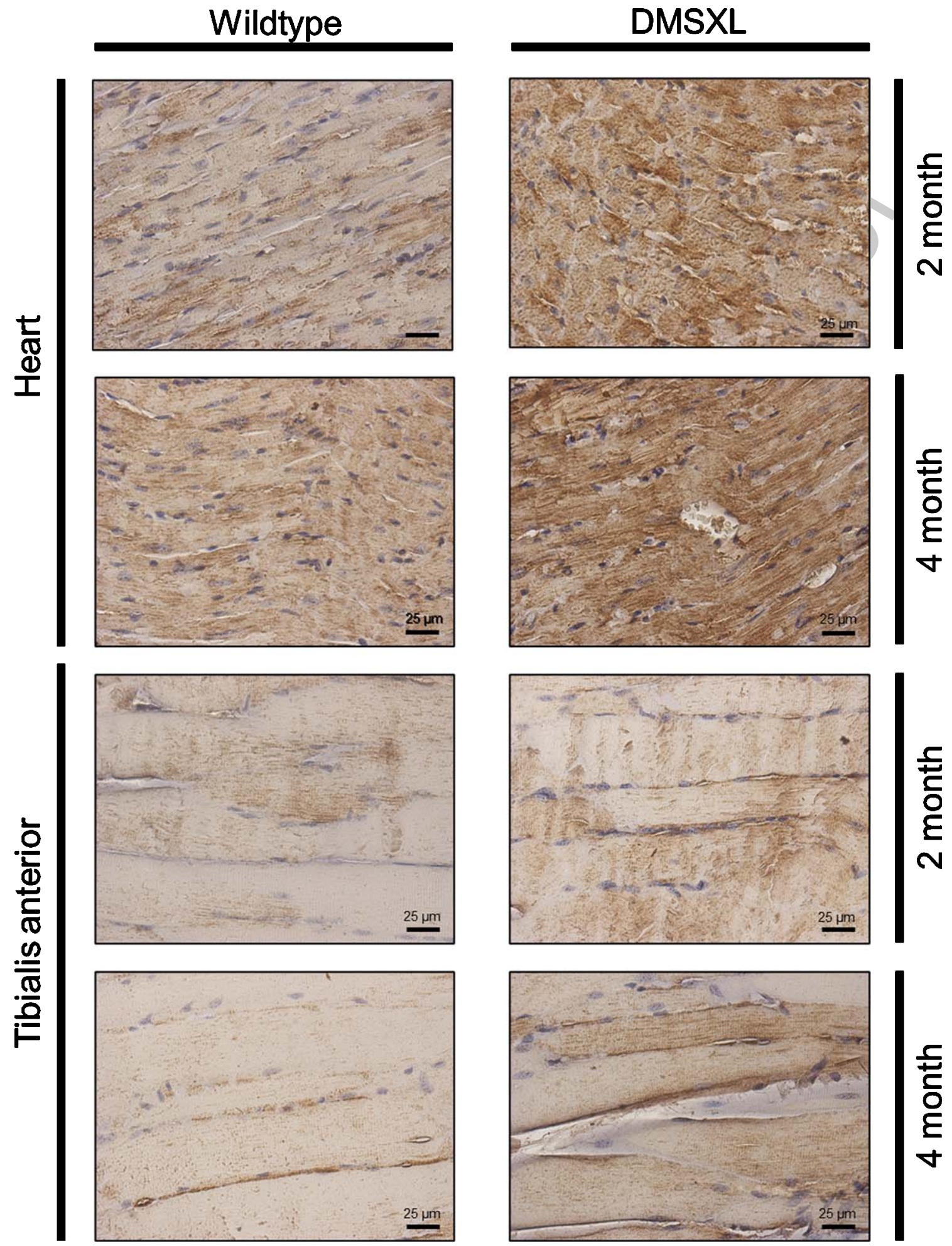

Fig. 3. Immunohistochemistry-based analysis of CAPN1 expression in cardiac and tibialis anterior muscle derived from DMSXL mice. Increased immunoreactivity of CAPN1 is detected in cardiac and tibialis anterior muscle (longitudinal sections) of diseased animals compared to controls at the age of two and four months. 
pathway) was linked to increased cancer risk [65]. We identified decreased CTNNB1-levels in fibroblasts of both mild and severely affected patients, and in accordance with the expression level of GSK3 $\beta$, this effect is more pronounced in mild patients rather than severe.

Heterogeneous nuclear ribonucleoprotein $\mathrm{H} 3(\mathrm{hn}$ RNPH3; decreased in DM1 fibroblasts): is an RNA binding protein involved in splicing, in particular by participating in early heat shock-induced splicing arrest [66]. Inhibition of GSK3 $\beta$ controls cellular levels of hnRNPH3, thus showing a functional interdependence of both proteins [67]. hnRNPH3 binds to splice regulator muscleblind 1 variants (MBNL1 CUG) that co-localize with CUG foci in DM1-patient-derived muscle cells [68]. Furthermore, hnRN PH3 levels are increased on average 3-fold in DM1 myoblasts [68], however, this is in contradiction with the decreased level observed in our study. This might be related to cell-type specific protein-composition of these foci, perhaps in turn influenced by cell type specific expression patterns of the related proteins.

Voltage-dependent anion-selective channel protein 2 (VDAC2; decreased in DM1 fibroblasts): localizes to the mitochondrial outer membrane where it constitutes a channel for the membrane transport of various substrates [69]. GSK3 $\beta$ is a major positive regulator of mitochondrial permeability during oxidative stress, a trigger of apoptosis, and interacts with VDAC2 [70]. Apart from its role in regulating the flux across the mitochondrial outer membrane, VDAC2 has a fundamental function in sequestering the proapoptotic protein BAK in the mitochondrial outer membrane and maintaining it in the inactive state [71].

Mitochondrial dysfunction and impaired oxidative metabolism are known pathophysiological mechanisms in DM1 [72, 73]. Impaired mitochondrial bioenergetics, accompanied by complex 1-dysfunction and decreased VDAC2 expression, were described in quadriceps and gastrocnemius muscle of $m d x$ mice, an animal model for Duchenne muscular dystrophy [74]. Hence, one might assume that the VDAC2-decrease in DM1 contributes to mitochondrial dysfunction and the initiation of apoptosis.

Calpain-1 catalytic subunit (CAPN1; increased in DM1 fibroblasts): also called $\mu$-calpain, belongs to a family of $\mathrm{Ca}^{2+}$-dependent cysteine proteases [75]. It is expressed ubiquitously as a heterodimer [76]. Calpains are involved in several physiological functions such as cytoskeletal remodeling [77], signal transduction [78], apoptosis [79], cell cycle [80], regulation of gene expression [81] and long-term potentiation [82]. Truncation and activation of GS $\mathrm{K} 3 \beta$ is modulated by CAPN1 [83] and recent evidence showed that GSK3 $\beta$ phosphorylates desmin filaments (an essential event for myofibril destruction) in a CAPN1 dependent manner [84]. In skeletal muscle, increasedcalpain activation was described in atrophic conditions following disuse, denervation, glucocorticoid treatment and sepsis [85-87] as well as in necrotic fibers from $m d x$ mice [88]. Moreover, elevated CAPN1 levels were found in sera samples of young DMD patients not yet treated with glucocorticoids, who also present with high levels of GSK3 $\beta$ that decline with aging [89]. Further evidence for a significant role of CAPN1 in muscle fibre integrity is given by in vivo studies: reduced muscle necrosis and, consequently, a significantly decreased regeneration was observed in $m d x$ mice crossed with transgenic animals overexpressing calpastatin, a CAPN1-inhibitor [90]. Based on these findings, one might suppose that increased CAPN1 levels may be linked to the dystrophic conditions characterizing DM1. Indeed, immunohistochemical studies of CAPN1 on cardiac and tibialis anterior muscles derived from DMSXL mice, a suitable DM1 mouse model, revealed an increase compared to wildtype littermates in both tissues. This molecular finding suggests an applicability of our proteomic findings on tissues of major vulnerability in DM1 such as cardiac and skeletal muscle.

CTP synthase 1 (CTPS1; increased in DM1 fibroblasts): is responsible for de novo synthesis of CTP (cytidine triphosphate) and biosynthesis of phospholipids, nucleic acids and in sustaining the proliferation of activated lymphocytes [91-93]. GSK3 $\beta$ is a known regulator of CTPS1 activity [94]. We hypothesize that the increased level of CTPS1 is linked to the alterations in lipid composition or metabolism that can occur during skeletal and cardiac myopathies [95]. With regards to the insulin resistance in the cardiac and skeletal muscles of DM1 patients and animal models (see below), it is worth noting that this not only results in increased circulating glucose but also lipid levels [96]. Thus, an interdependent coregulation of both CTPS1 and NR3C1 in a GSK3 $\beta$ dependent manner might be plausible.

Glucocorticoid receptor ( $\mathrm{NR} 3 \mathrm{C} 1$; increased in DM1 fibroblasts): is a member of the superfamily of nuclear receptors (acting as modulators of gene transcription) that, in the absence of glucocorticoid/ cortisol, localizes to the cytosol in a chaperonecontaining multiprotein complex [97]. GSK3 $\beta$ is 
involved in ligand-dependent activation of transcription and cellular localization of this receptor [98]. A study performed in a large cohort of DM1 patients revealed alterations in glucocorticoid metabolism with an increased reactivation of cortisone to cortisol, mainly in male patients [99]. An excess of glucocorticoids leads to insulin resistance, which is also present in 5-17\% of DM1 cases [100, 101]. In skeletal muscle, insulin resistance leads to impaired glucose uptake into the muscle fibers where it is required as an energy source. Due to insulin resistance and subsequent lipid metabolism alterations, DM1 patients can present with cardiac and vascular defects [101]. Therefore, increased NR3C1 might serve as a marker for the presence of DM1.

Histone deacetylase 2 (HDAC2; increased in DM1 fibroblasts): is a chromatin modifying enzyme that prevents gene-transcription by removal of acetyl groups from histones and deacetylates proteins such as transcription factors and those involved in the control of cell growth, differentiation and apoptosis [102]. HDAC2 expression and function is known to be controlled by GSK3 $\beta[103,104]$. In the context of DM1 pathophysiology it is important to note that two small molecule HDAC inhibitors, ISOX and vorinostat, increase MBNL1 expression, partially rescuing aberrant splicing in DM1 patient-derived fibroblasts [105]. HDAC2 might represent a marker protein in DM1-patient derived fibroblasts that plays a direct role in DM1 pathophysiology.

Dual specificity mitogen-activated protein kinase kinase 2 (MAP2K2; increased in DM1 fibroblasts): also known as MEK2, is a ubiquitously expressed protein that catalyses the phosphorylation of tyrosine and threonine in target proteins participating in the RAS-RAF-MEK-ERK signal transduction cascade. Consequently, via this cascade, MEK2 is involved in the regulation of a variety of processes including apoptosis, cell cycle progression, cell migration, differentiation, metabolism, and proliferation [106]. It also modulates phosphorylation and thus function of GSK3 $\beta$ via ERK [34]. Of particular interest for the muscle vulnerability of DM1, the MEK-ERK pathway is important in muscle cell differentiation [107]. Sustained activation of this pathway presumably also includes MEK2, as found in DM1 myoblasts, and can be considered as a contributor to the abnormal myoblast differentiation observed [108]. Moreover, RAS-ERK pathway activation is known to regulate alternative splicing [109], the main pathophysiological process in DM1. One of the most common symptoms in DM1, myotonia, is based on aberrant splicing of the skeletal muscle chloride channel (CLCNI) transcript $[110,111]$ and RAS pathway inhibitors correct this alternative splicing, alleviating some DM1 features in mice [112].

Although a transfer of the relevance of the proteomic data acquired from human skin fibroblasts could be demonstrated for CAPN1 in skeletal muscle utilizing a DM1 mouse model, further biochemical investigations would be needed to draw the same conclusion for the other marker proteins highlighted in this study. Along this line, confirmational studies on fibroblasts derived from further DM1 patients would be needed to substantiate the robustness of the proposed cellular marker proteins.

\section{CONCLUSIONS}

Overall, in this study we have identified nine proteins associated with GSK $3 \beta$ that may provide muchneeded biomarkers for DM1 disease identification using easily obtained patient fibroblasts. Furthermore, we have also identified three proteins (CTPS1, CAPN1 and HDAC2) that increase with severity of the disease, providing potential biomarkers that can be used in categorizing patients, monitoring disease progression and response to treatment. Validation of such biomarkers and their hypothesized roles in DM1 and GSK3 $\beta$-associated pathophysiology will be required in future studies. Given that recent clinical trials in DM1 are based on GSK3 $\beta$-inhibition [113], as the proteins defined in our study, due to their interaction with GSK3 3 ,may serve as suitable markers to monitor success of the tested treatment concepts.

\section{DECLARATIONS}

Funding

Financial support by the Ministerium für Innovation, Wissenschaft und Forschung des Landes Nordrhein-Westfalen, the Senatsverwaltung für Wirtschaft, Technologie und Forschung des Landes Berlin and the Bundesministerium für Bildung und Forschung is gratefully acknowledged. This work was also supported by an unconditional grant from AMO pharma as well as a grant from the French Muscular Dystrophy Association (AFM-Téléthon; \#21466) to AR. HL receives support from the Canadian Institutes of Health Research (Foundation Grant FDN-167281), the Canadian Institutes of Health Research and Muscular Dystrophy Canada (Network 
Catalyst Grant for NMD4C), the Canada Foundation for Innovation (CFI-JELF 38412), and the Canada Research Chairs program (Canada Research Chair in Neuromuscular Genomics and Health, 950-232279).

\section{ACKNOWLEDGMENTS}

We thank Mr. Daniel Cox (MRC biobank Newcastle) for expert technical assistance.

\section{CONFLICTS OF INTEREST/ COMPETING INTERESTS}

All authors declare no conflict of interest.

\section{AUTHORS' CONTRIBUTIONS}

AR, DH and HL designed the study. NN collected skin biopsies and provided clinical information. DH performed proteomic studies. AH performed data analysis and in silico studies. VG, EOC, USS, HL \& AR drafted the manuscript. GG provided the tissue of the DM1 mouse model. All authors declare that the work described has not been published before and is also not under consideration for publication anywhere else. The final manuscript-draft has been approved by all co-authors.

\section{SUPPLEMENTARY MATERIAL}

The supplementary material is available in the electronic version of this article: https:// dx.doi.org/10.3233/JND-200558.

\section{REFERENCES}

[1] Theadom A, Rodrigues M, Roxburgh R, Balalla S, Higgins C, Bhattacharjee R, et al. Prevalence of muscular dystrophies: A systematic literature review. Neuroepidemiology. 2014;43(3-4):259-68. https://doi.org/10. $1159 / 000369343$.

[2] Mathieu J, De Braekeleer M, Prévost C.Genealogical reconstruction of myotonic dystrophy in the SaguenayLac-Saint- Jean area (Quebec, Canada). Neurology. 1990;40(5):839. https://doi.org/10.1212/WNL.40.5.839.

[3] Yotova V, Labuda D, Zietkiewicz E, Gehl D, Lovell A, Lefebvre JF et al. Anatomy of a founder effect: Myotonic dystrophy in Northeastern Quebec. HUM GENET. 2005;117(2-3):177-87. https://doi.org/10.1007/s00439005-1298-8.

[4] Pinessi L, Bergamini L, Cantello R, Di Tizio C. Myotonia congenita and myotonic dystrophy: Descriptive epidemiological investigation in Turin, Italy (19551979). Ital J Neurol Sci. 1982;3(3):207-10. https://doi. org/10.1007/BF02043311.
[5] Meola G and Cardani R. Myotonic dystrophies: An update on clinical aspects, genetic, pathology, and molecular pathomechanisms. Biochim Biophys Acta. 2015;1852(4):594606. https://doi.org/10.1016/j.bbadis.2014.05.019.

[6] De Antonio M, Dogan C, Hamroun D, Mati M, Zerrouki S, Eymard B, et al. French Myotonic Dystrophy Clinical Network. Unravelling the myotonic dystrophy type 1 clinical spectrum: A systematic registry-based study with implications for disease classification. Rev Neurol (Paris). 2016;172(10):572-80. https://doi.org/10.1016/ j.neurol.2016.08.003.

[7] Brook JD, McCurrach ME, Harley HG, Buckler AJ, Church D, Aburatani H, et al. Molecular basis of myotonic dystrophy: Expansion of a trinucleotide (CTG) repeat at the 3' end of a transcript encoding a protein kinase family member. Cell. 1992;69(2):385. https://doi. org/10.1016/0092-8674(92)90154-5.

[8] Harley HG, Rundle SA, MacMillan JC, Myring J, Brook JD, Crow S, et al. Size of the unstable CTG repeat sequence in relation to phenotype and parental transmission in myotonic dystrophy. Am J Hum Genet. 1993;52(6):116474.

[9] De Temmerman N, Sermon K, Seneca S, De Rycke M, Hilven P, Lissens W, et al.Intergenerational instability of the expanded CTG repeat in the DMPK gene: Studies in human gametes and preimplantation embryos. Am J Hum Genet. 2004;75(2):325-9. http://dx. doi.org/10.1086/422762.

[10] Yum K, Wang ET, Kalsotra A. Myotonic dystrophy: Disease repeat range, penetrance, age of onset, and relationship between repeat size and phenotypes. Curr Opin Genet Dev. 2017;44:30-7. http://dx.doi.org/10.1016/j. gde.2017.01.007.

[11] Harley HG, Rundle SA, Reardon W, Myring J, Crow S, Brook JD, et al. Unstable DNA sequence in myotonic dystrophy. Lancet. 1992;339(8802):1125-8. http://dx.doi. org/10.1016/0140-6736(92)90729-m.

[12] Klein AF, Gasnier E, Furling D. Gain of RNA function in pathological cases: Focus on myotonic dystrophy. Biochimie. 2011;93(11):2006-12. http://dx.doi.org/ 10.1016/j.biochi.2011.06.028.

[13] Thomas JD, Sznajder LJ, Bardhi O, Aslam FN, Anastasiadis ZP, Scotti MM, et al.Disrupted prenatal RNA processing and myogenesis in congenital myotonic dystrophy. Genes Dev. 2017;31(11):1122-33. http://dx.doi. org/10.1101/gad.300590.117.

[14] Holt I, Jacquemin V, Fardaei M, Sewry CA, ButlerBrowne GS, Furling D, et al. Muscleblind-like proteins: Similarities and differences in normal and myotonic dystrophy muscle. Am J Pathol. 2009;174(1):216-27. http:// dx.doi.org/10.2353/ajpath.2009.080520.

[15] Lin X, Miller JW, Mankodi A, Kanadia RN, Yuan Y, Moxley RT, et al. Failure of MBNL1-dependent post-natal splicing transitions in myotonic dystrophy. Hum Mol Genet. 2006;15(13):2087-97. http://dx.doi.org/ $10.1093 / \mathrm{hmg} / \mathrm{ddl} 132$.

[16] Cardani R, Bugiardini E, Renna LV, Rossi G, Colombo $\mathrm{G}$, Valaperta R, et al.Overexpression of CUGBP1 in skeletal muscle from adult classic myotonic dystrophy type 1 but not from myotonic dystrophy type 2. PLoS One. 2013;8(12):e83777. https://doi.org/10.1371/journal. pone. 0083777 .

[17] Gomes-Pereira M, Cooper TA, Gourdon G. Myotonic dystrophy mouse models: Towards rational therapy development. Trends Mol Med. 2011;17(9):506-17. http://dx. doi.org/10.1016/j.molmed.2011.05.004. 
[18] Choi J, Personius KE, DiFranco M, Dansithong W, Yu C, Srivastava S, et al. Muscleblind-Like 1 and Muscleblind-Like 3 Depletion Synergistically Enhances Myotonia by Altering Clc-1 RNA Translation. EBio Medicine. 2015;2(9):1034-47. http://dx.doi.org/10.1016/ j.ebiom.2015.07.028.

[19] Kino Y, Washizu C, Oma Y, Onishi H, Nezu Y, Sasagawa $\mathrm{N}$, et al. MBNL and CELF proteins regulate alternative splicing of the skeletal muscle chloride channel CLCN1. Nucleic Acids Res. 2009;37(19):6477-90. http:// dx.doi.org/10.1093/nar/gkp681.

[20] Bachinski LL, Baggerly KA, Neubauer VL, Nixon TJ, Raheem O, Sirito M, et al. Most expression and splicing changes in myotonic dystrophy type 1 and type 2 skeletal muscle are shared with other muscular dystrophies. Neuromuscul Disord. 2014;24(3):227-40. http:// dx.doi.org/10.1016/j.nmd.2013.11.001.

[21] Santoro M, Piacentini R, Masciullo M, Bianchi ML, Modoni A, Podda MV, et al. Alternative splicing alterations of $\mathrm{Ca} 2+$ handling genes are associated with $\mathrm{Ca} 2+$ signal dysregulation in myotonic dystrophy type 1 (DM1) and type 2 (DM2) myotubes. Neuropathol Appl Neurobiol. 2014;40(4):464-76. http://dx.doi.org/10.1111/nan. 12076.

[22] Vihola A, Bachinski LL, Sirito M, Olufemi SE, Hajibashi S, Baggerly KA, et al. Differences in aberrant expression and splicing of sarcomeric proteins in the myotonic dystrophies DM1 and DM2. Acta Neuropathol. 2010;119(4):465-79. http://dx.doi.org/10.1007/s00401010-0637-6.

[23] Freyermuth F, Rau F, Kokunai Y, Linke T, Sellier C, Nakamori $\mathrm{M}$, et al.Splicing misregulation of SCN5A contributes to cardiac-conduction delay and heart arrhythmia in myotonic dystrophy. Nat Commun. 2016;7:11067. http://dx.doi.org/10.1038/ncomms11067.

[24] Suenaga K, Lee KY, Nakamori M, Tatsumi Y, Takahashi MP, Fujimura H, et al. Muscleblind-like 1 knockout mice reveal novel splicing defects in the myotonic dystrophy brain. PLoS One. 2012;7(3):e33218. http://dx.doi. org/10.1371/journal.pone.0033218.

[25] Charizanis K, Lee KY, Batra R, Goodwin M, Zhang C, Yuan Y, et al. Muscleblind-like 2-mediated alternative splicing in the developing brain and dysregulation in myotonic dystrophy. Neuron. 2012;75(3):437-50. http:// dx.doi.org/10.1016/j.neuron.2012.05.029.

[26] Paul S, Dansithong W, Kim D, Rossi J, Webster NJ, Comai L, et al. Interaction of muscleblind, CUG-BP1 and hnRNP H proteins in DM1-associated aberrant IR splicing. EMBO J. 2006;25(18):4271-83. http://dx.doi.org/ 10.1038/sj.emboj.7601296.

[27] Sen S, Talukdar I, Webster NJ. SRp20 and CUG-BP1 modulate insulin receptor exon 11 alternative splicing. Mol Cell Biol. 2009;29(3):871-80. http://dx.doi.org/ 10.1128/MCB.01709-08.

[28] Sen S, Talukdar I, Liu Y, Tam J, Reddy S, Webster NJ.Muscleblind-like 1 (Mbnl1) promotes insulin receptor exon 11 inclusion via binding to a downstream evolutionarily conserved intronic enhancer. J Biol Chem. 2010;285(33):25426-37. http://dx.doi.org/10.1074/jbc.M 109.095224

[29] Jones K, Wei C, Iakova P, Bugiardini E, Schneider-Gold C, Meola G, et al. GSK3beta mediates muscle pathology in myotonic dystrophy. J Clin Invest. 2012;122(12):4461-72. http://dx.doi.org/10.1172/JCI64081.
[30] Beurel E, Grieco SF, Jope RS.Glycogen synthase kinase-3 (GSK3): Regulation, actions, and diseases. Pharmacol Ther. 2015;148:114-31. http://dx.doi.org/10. 1016/j.pharmthera.2014.11.016.

[31] Sutherland C. What Are the bona fide GSK3 Substrates? Int J Alzheimers Dis. 2011;2011:505607. http://dx.doi. org/10.4061/2011/505607.

[32] Verhees KJ, Pansters NA, Schols AM, Langen RC. Regulation of skeletal muscle plasticity by glycogen synthase kinase-3beta: A potential target for the treatment of muscle wasting. Curr Pharm Des. 2013;19(18):3276-98. http: //dx.doi.org/10.2174/1381612811319180011

[33] Pardo M, Abrial E, Jope RS, Beurel E. GSK3beta isoform-selective regulation of depression, memory and hippocampal cell proliferation. Genes Brain Behav. 2016; 15(3):348-55. http://dx.doi.org/10.1111/gbb.12283.

[34] Bradley CA, Peineau S, Taghibiglou C, Nicolas CS, Whitcomb DJ, Bortolotto ZA, et al. A pivotal role of GSK-3 in synaptic plasticity. Front Mol Neurosci. 2012;5:13. http:// dx.doi.org/10.3389/fnmol.2012.00013.

[35] Wei C, Jones K, Timchenko NA, Timchenko L. GSK3beta is a new therapeutic target for myotonic dystrophy type 1. Rare Dis. 2013;1:e26555. http://dx.doi.org/10.4161/ rdis. 26555 .

[36] Hentschel A, Czech A, Münchberg U, Freier E, ScharaSchmidt U, Sickmann A, et al. Protein Signature of Human Skin Fibroblasts Allows the Study of the Molecular Etiology of Rare Neurological Diseases. Research Square; 2020. http://dx.doi.org/10.21203/rs.3.rs-48014/v1.

[37] Reza M, Cox D, Phillips L, Johnson D, Manoharan V, Grieves M, et al. MRC Centre Neuromuscular Biobank (Newcastle and London): Supporting and facilitating rare and neuromuscular disease research worldwide. Neuromuscular Disord. 2017;27(11):1054-64. http://dx.doi.org/ 10.1016/j.nmd.2017.07.001

[38] Manza LL, Stamer SL, Ham AJ, Codreanu SG, Liebler DC. Sample preparation and digestion for proteomic analyses using spin filters. Proteomics. 2005;5(7):1742-5. http://dx.doi.org/10.1002/pmic.200401063.

[39] Wisniewski JR, Zougman A, Nagaraj N, Mann M. Universal sample preparation method for proteome analysis. Nat Methods. 2009;6:359-362. https://doi.org/10.1038/ nmeth.1322.

[40] Burkhart JM, Schumbrutzki C, Wortelkamp S, Sickmann A, Zahedi RP. Systemic and quantitative comparison of digest efficiency and specificity reveals the impact of trypsin quality on MS-based proteomics. J Proteomics. 2012;75:1454-62. http://dx.doi.org/10.1016/j.jprot.2011. 11.016.

[41] Phan V, Schmidt J, Matyash V, Malchow S, Thanisch M, Lorenz C, et al.Characterization of Naïve and Vitamin C-Treated Mouse Schwann Cell Line MSC80: Induction of the Antioxidative Thioredoxin Related Transmembrane Protein 1. J Proteome Res. 2018;17(9):2925-36. http://dx doi.org/10.1021/acs.jproteome.8b00022.

[42] Vaudel M, Barsnes H, Berven FS, Sickmann A, Martens L. SearchGUI: An open-source graphical user interface for simultaneous OMSSA and X!Tandem searches. Proteomics. 2011;11:996-9. http://dx.doi.org/10.1002/ pmic. 201000595 .

[43] Vaudel M, Burkhart JM, Zahedi RP, Oveland E, Berven FS, Sickmann A, et al. PeptideShaker enables reanalysis of MS-derived proteomics data sets. Nat Biotechnol. 2015;33(1):22-4. http://dx.doi.org/10.1038/nbt.3109. 
[44] Huguet A, Medja F, Nicole A, Vignaud A, GuiraudDogan C, Ferry A, et al. Molecular, physiological, and motor performance defects in DMSXL mice carrying $>1,000$ CTG repeats from the human DM1 locus. PLoS Genet. 2012;8(11):e1003043. http://dx.doi.org/10.1371/ journal.pgen.1003043.

[45] Roos A, Buchkremer S, Kollipara L, Labisch T, Gatz C, Zitzelsberger M, et al. Myopathy in Marinesco-Sjögren syndrome links endoplasmic reticulum chaperone dysfunction to nuclear envelope pathology. Acta Neuropathol. 2014;127(5):761-77. http://dx.doi.org/10.1007/s00401013-1224-4.

[46] Roos A, Thompson R, Horvath R, Lochmüller H, Sickmann A. Intersection of Proteomics and Genomics to "Solve the Unsolved" in Rare Disorders such as Neurodegenerative and Neuromuscular Diseases. PROTEOM CLIN APPL. 2017;12(2):1700073. http://dx.doi.org/10. 1002/prca.201700073.

[47] Thompson R, Spendiff S, Roos A, Bourque PR, Warman Chardon J, Kirschner J, et al. Advances in the diagnosis of inherited neuromuscular diseases and implications for therapy development. Lancet Neurol. 2020;19(6):522-32. http://dx.doi.org/10.1016/S1474-4422(20)30028-4.

[48] Rodríguez R, Hernández-Hernández O, Magaña JJ, González-Ramírez R, García-López ES, Cisneros B. Altered nuclear structure in myotonic dystrophy type 1derived fibroblasts. Mol Biol Rep. 2014;42(2):479-88. http://dx.doi.org/10.1007/s11033-014-3791-4.

[49] Jope RS and Johnson GVW. The glamour and gloom of glycogen synthase kinase-3. Trends in Biochemical Sciences. 2004;29(2):95-102. https://doi.org/10. 1016/j.tibs.2003.12.004.

[50] Morriss GR, Rajapakshe K, Huang S, Coarfa C and Cooper TA. Mechanisms of skeletal muscle wasting in a mouse model for myotonic dystrophy type 1.Hum Mol Genet. 2018;27(16):2789-804. https://doi.org/10. 1093/hmg/ddy 192.

[51] Gujar H, Weisenberger DJ, Liang G. The Roles of Human DNA Methyltransferases and Their Isoforms in Shaping the Epigenome. Genes. 2019;10(2):172. http://dx.doi. org/10.3390/genes 10020172 .

[52] Koh HB, Scruggs AM, Huang SK. Transforming Growth Factor- $\beta 1$ Increases DNA Methyltransferase 1 and 3a Expression through Distinct Post-transcriptional Mechanisms in Lung Fibroblasts. J BIOL CHEM. 2016;291(37):19287-98. http://dx.doi.org/10.1074/jbc.m 116.723080

[53] Amack JD, Mahadevan MS. Myogenic defects in myotonic dystrophy. Dev Biol. 2004;265(2):294-301. http://dx.doi.org/10.1016/j.ydbio.2003.07.021.

[54] André LM, Ausems CRM, Wansink DG, Wieringa B. Abnormalities in Skeletal Muscle Myogenesis, Growth, and Regeneration in Myotonic Dystrophy. Front Neurol. 2018;9:368. http://dx.doi.org/10.3389/fneur.2018.00368.

[55] Liu R, Kim KY, Jung YW, Park IH. Dnmt1 regulates the myogenic lineage specification of muscle stem cells. Sci Rep. 2016;6:35355. http://dx.doi.org/10.1038/srep 35355.

[56] Dion V, Lin Y, Hubert L, Waterland RA, Wilson JH. Dnmt1 deficiency promotes CAG repeat expansion in the mouse germline. Hum Mol Genet. 2008;17(9):1306-317. http://dx.doi.org/10.1093/hmg/ddn019.

[57] Xie H, Liu Y, Du R, Wang B, Chen M, Zhang Y, et al. miR-377 induces senescence in human skin fibroblasts by targeting DNA methyltransferase 1.CELL
DEATH DIS. 2017;8(3):e2663-e2663. http://dx.doi.org/ 10.1038/cddis.2017.75.

[58] Campione E, Botta A, Di Prete M, Rastelli E, Gibellini M, Petrucci A, et al. Cutaneous features of myotonic dystrophy types 1 and 2: Implication of premature aging and vitamin D homeostasis. Neuromuscul Disord. 2017;27(2):163-9. http://dx.doi.org/10.1016/j.nmd. 2016.11.004.

[59] Girardi F, Le Grand F. Wnt signaling in skeletal muscle development and regeneration. Progress in Molecular Biology and Translational Science. 2018;153:157-79. https://doi.org/10.1016/bs.pmbts.2017.11.026

[60] van der Velden JLJ, Langen RCJ, Kelders MCJM, Wouters EFM, Janssen-Heininger YMW, Schols AMWJ Inhibition of glycogen synthase kinase-3 $\beta$ activity is sufficient to stimulate myogenic differentiation. AmJ Physiol Cell Physiol. 2006;290(2):C453-C462. https://doi.org/ 10.1152/ajpcell.00068.2005.

[61] Han XH, Jin Y-R, Seto M, Yoon JK. A WNT/ $\beta$-catenin signaling activator, $\mathrm{R}$-spondin, plays positive regulatory roles during skeletal myogenesis. J Biol Chem. 2011;286(12):10649-59. https://doi.org/10.1074/jbc.M1 10.169391 .

[62] Rochat A, Fernandez A, Vandromme M, Molès JP, Bouschet T, Carnac G, Lamb NJC. Insulin and Wnt1 pathways cooperate to induce reserve cell activation in differentiation and myotube hypertrophy. MolBiolCell. 2004;15(10):4544-55. https://doi.org/10.1091/ mbc.E03-11-0816.

[63] Biressi S, Miyabara EH, Gopinath SD, Carlig PMM, Rando TA. A Wnt-TGFß2 axis induces a fibrogenic program in muscle stem cells from dystrophic mice. SciTransl Med. 2014;6(267):267ra176. https://doi.org/10. 1126/scitranslmed.3008411.

[64] Trensz F, Haroun S, Cloutier A, Richter MV, Grenier G. A muscle resident cell population promotes fibrosis in hindlimb skeletal muscles of mdx mice through the Wnt canonical pathway. Am J Physiol Cell Physiol. 2010;299(5):C939-C947. https://doi.org/10.1152/ajp cell.00253.2010.

[65] Mueller CM, Hilbert JE, Martens W, Thornton CA, Moxley RT, Greene MH. Hypothesis: Neoplasms in myotonic dystrophy. Cancer Causes Control. 2009;20(10):2009-20. https://doi.org/10.1007/s10552-009-9395-y.

[66] Mahe' D, Mähl P, Gattoni R, Fischer N, Mattei MG, Stevenin J, Fuchs JP. Cloning of Human 2H9 Heterogeneous Nuclear Ribonucleoproteins. Relation With Splicing and Early Heat Shock-Induced Splicing Arrest. J Biol Chem. 1997;272(3):1827-36. http://dx.doi. org/10.1074/jbc.272.3.1827.

[67] Wang Z, Pandey A, Hart GW. Dynamic Interplay betweenO-LinkedN-Acetylglucosaminylation and Glycogen Synthase Kinase-3-dependent Phosphorylation. MOL CELLPROTEOMICS. 2007;6(8):1365-79. http:// dx.doi.org/10.1074/mcp.m600453-mcp200.

[68] Paul S, Dansithong W, Jog SP, Holt I, Mittal S, Brook JD, et al. Expanded CUG repeats Dysregulate RNA splicing by altering the stoichiometry of the muscleblind 1 complex. J Biol Chem. 2011;286:38427-38. http://dx. doi.org/10.1074/jbc.M111.255224.

[69] Naghdi S, Hajnóczky G. VDAC2-specific cellular functions and the underlying structure. Biochim Biophys Acta. 2016;1863(10):2503-514. http://dx.doi.org/10. 1016/j.bbamcr.2016.04.020 
[70] Tanno M, Kuno A, Ishikawa S, Miki T, Kouzu H, Yano $\mathrm{T}$, et al. Translocation of Glycogen Synthase Kinase$3 \beta$ (GSK-3 $\beta$ ), a Trigger of Permeability Transition, Is Kinase Activity-dependent and Mediated by Interaction with Voltage-dependent Anion Channel 2 (VDAC2). J BIOL CHEM. 2014;289(42):29285-96. http://dx.doi.org/ 10.1074/jbc.m114.563924.

[71] De Pinto V, Reina S, Gupta A, Messina A, Mahalakshmi R. Role of Cysteines in Mammalian VDAC Isoforms' Function. Biochim Biophys Acta. 2016;1857(8):1219-27. http://dx.doi.org/10.1016/j.bbabio.2016.02.020.

[72] Toscano A, Messina S, Campo GM, Di Leo R, Musumeci $\mathrm{O}$, Rodolico $\mathrm{C}$, et al. Oxidative stress in myotonic dystrophy type 1. Free Radic Res. 2005;39(7):771-76. http://dx.doi.org/10.1080/10715760500138932.

[73] Gramegna LL, Giannoccaro MP, Manners DN, Testa C, Zanigni S, Evangelisti S, et al. Mitochondrial dysfunction in myotonic dystrophy type 1 . Neuromuscul Disord. 2018;28(2):144-9. http://dx.doi.org/10.1016/j. nmd.2017.10.007.

[74] Hughes MC, Ramos SV, Tumbull PC, Rebalka IA, Cao A, Monaco CMF, et al. Early Myopathy in Duchenne Muscular Dystrophy Is Associated With Elevated Mitochondrial $\mathrm{H}_{2} \mathrm{O}_{2}$ Emission During Impaired Oxidative Phosphorylation. J Cachexia Sarcopenia Muscle. 2019;10(3):643-61. http://dx.doi.org/10.1002/jcsm.12405.

[75] Goll DE, Thompson VF, Li H, Wei W, Cong J. The calpain system. Physiol Rev. 2003;83:731-801. https:// doi.org/10.1152/physrev.00029.2002.

[76] Lin GD, Chattopadhyay D, Maki M, Wang KK, Carson M, Jin L, et al. Crystal structure of calcium bound domain VI of calpain at 1.9 A resolution and its role in enzyme assembly, regulation, and inhibitor binding. Nat Struct Biol. 1997;4:539-47. https://doi.org/10.1038/nsb0797-539.

[77] Mazères G, Leloup L, Daury L, Cottin P, Brustis JJ. Myoblast attachment and spreading are regulated by different patterns by ubiquitous calpains. Cell Motil Cytoskeleton. 2006;63:193-207. https://doi.org/10.1002/cm. 20116.

[78] Jungwirth U, Gojo J, Tuder T, Walko G, Holcmann M, Schöfl T, et al. Calpain-mediated integrin deregulation as a novel mode of action for the anticancer gallium compound KP46. Mol Cancer Ther. 2014;13:2436-49. https://doi.org/10.1158/1535-7163.MCT-14-0087.

[79] Nozaki K, Das A, Ray SK, Banik NL. Calpeptin attenuated apoptosis and intracellular inflammatory changes in muscle cell. J Neurosci Res. 2011;89:536-43. https:// doi.org/10.1002/jnr.22585.

[80] Liang Z, Brown RC, Fletcher JC, Opsahl-Sorteberg HG. Calpain-mediated positional information directs cell wall orientation to sustain plant stem cell activity, growth and development. Plant Cell Physiol. 2015;56:1855-66. https://doi.org/10.1093/pcp/pcv110.

[81] Qin QY, Liao GH, Michel B, Bi XN. Role of calpainmediated p53 truncation in semaphorin 3A-induced axonal growth regulation. Proc Natl Acad Sci U S A. 2010;107:13883-87. https://doi.org/10.1073/pnas.1008 652107.

[82] Lynch G. Memory and the brain: Unexpected chemistries and a new pharmacology. Neurobiol Learn Mem. 1998; 70:82-100. https://doi.org/10.1006/nlme.1998.3840.

[83] Jin N, Yin X, Yu D, Cao M, Gong CX, Iqbal K, et al. Truncation and activation of GSK-3 $\beta$ by calpain I: A molecular mechanism links to tau hyperphosphoryla- tion in Alzheimer's disease. Sci Rep. 2015;5:8187. https:// doi.org/10.1038/srep08187.

[84] Aweida D, Rudesky I, Volodin A, Shimko E, Cohen S. GSK3- $\beta$ promotes calpain-1-mediated desmin filament depolymerization and myofibril loss in atrophy. J Cell Biol. 2018;217(10):3698-714. https://doi.org/ 10.1083/jcb.201802018.

[85] Nelson WB, Smuder AJ, Hudson MB, Talbert EE, Powers SK. Cross-talk between the calpain and caspase-3 proteolytic systems in the diaphragm during prolonged mechanical ventilation. Crit Care Med. 2012;40:1857-63. https://doi.org/10.1097/CCM.0b013e318246bb5d.

[86] Matsumoto A, Fujita N, Arakawa T, Fujino H, Miki A. Influence of electrical stimulation on calpain and ubiquitin-proteasome systems in the denervated and unloaded rat tibialis anterior muscles. Acta Histochem. 2014;116:936-42. https://doi.org/10.1016/j.acthis.2014. 03.006 .

[87] Fareed MU, Evenson AR, Wei W, Menconi M, Poylin V, Petkova V, et al. Treatment of rats with calpain inhibitors prevents sepsis-induced muscle proteolysis independent of atrogin-1/MAFbx and MuRF1 expression. Am J Physiol Regul Integr Comp Physiol. 2006;290:R1589-R1597. https://doi.org/10.1152/ajpregu.00668.2005.

[88] Spencer MJ, Croall DE, Tidball JG. Calpains are activated in necrotic fibers from $\mathrm{mdx}$ dystrophic mice. J Biol Chem. 1995;270(18):10,909-10,914. https://doi.org/ 10.1074/jbc.270.18.10909.

[89] Hathout Y, Liang C, Ogundele M, Xu G, Tawalbeh SM, Dang UJ, et al. Disease-specific and glucocorticoidresponsive serum biomarkers for Duchenne Muscular Dystrophy. Sci Rep. 2019;9(1):12167. https://doi.org/10. 1038/s41598-019-48548-9.

[90] Spencer MJ, Mellgren RL. Overexpression of a calpastatin transgene in $\mathrm{mdx}$ muscle reduces dystrophic pathology. Hum Mol Genet. 2002;11:2645-55. https://doi. org/10.1093/hmg/11.21.2645.

[91] Evans DR, Guy HI. Mammalian pyrimidine biosynthesis: Fresh insights into an ancient pathway. J Biol Chem. 2004;279:33035-8. http://dx.doi.org/10.1074/ jbc.R400007200.

[92] Ostrander DB, O'Brien DJ, Gorman JA, Carman GM. Effect of CTP synthetase regulation by CTP on phospholipid synthesis in Saccharomyces cerevisiae. J Biol Chem. 1998;273:18992-9001. http://dx.doi.org/ 10.1074/jbc.273.30.18992.

[93] Martin E, Palmic N, Sanquer S, Lenoir C, Hauck F, Mongellaz C, et al. CTP synthase 1 deficiency in humans reveals its central role in lymphocyte proliferation. Nature. 2014;510(7504):288-92. http://dx.doi.org/10. 1038/nature13386.

[94] Higgins MJ, Graves PR, Graves LM. Regulation of Human Cytidine Triphosphate Synthetase 1 by Glycogen Synthase Kinase 3. J Biol Chem. 2007;282(40):29493-503. http://dx.doi.org/10.1074/jbc.m703948200.

[95] Saini-Chohan HK, Mitchell RW, Vaz FM, Zelinski T, Hatch GM. Delineating the role of alterations in lipid metabolism to the pathogenesis of inherited skeletal and cardiac muscle disorders. J Lipid Res. 2011;53(1):4-27. http://dx.doi.org/10.1194/jlr.R012120.

[96] Llagostera E, Catalucci D, Marti L, Liesa M, Camps M, Ciaraldi TP et al. Role of Myotonic Dystrophy Protein Kinase (DMPK) in Glucose Homeostasis and Muscle Insulin Action. PLoS ONE. 2007;2(11):e1134. http://dx. doi.org/10.1371/journal.pone.0001134. 
[97] Schoneveld OJLM, Gaemers IC, Lamers WH. Mechanisms of glucocorticoid signalling. Biochimica et Biophysica Acta (BBA) - Gene Structure and Expression. 2004;1680(2):114-28. http://dx.doi.org/10.1016/j. bbaexp.2004.09.004.

[98] Rubio-Patiño C, Palmeri CM, Pérez-Perarnau A, Cosialls AM, Moncunill-Massaguer C, González-Gironès DM, et al. Glycogen Synthase Kinase-3 $\beta$ Is Involved in Ligand-Dependent Activation of Transcription and Cellular Localization of the Glucocorticoid Receptor. MOLENDOCRINOL. 2012;26(9):1508-20. http://dx.doi. org/10.1210/me.2011-1366.

[99] Johansson $\AA$, Andrew R, Forsberg H, Cederquist K, Walker BR, Olsson T. Glucocorticoid Metabolism and Adrenocortical Reactivity to ACTH in Myotonic Dystrophy. J Clin Endocrinol Metab. 2001;86:4276-83. http://dx.doi.org/10.1210/jcem.86.9.7865.

[100] Ruzzin J, Wagman AS, Jensen J. Glucocorticoid-induced insulin resistance in skeletal muscles: Defects in insulin signalling and the effects of a selective glycogen synthase kinase-3 inhibitor. Diabetologia. 2005;48:2119-30. http://dx.doi.org/10.1007/s00125-005-1886-0.

[101] Nieuwenhuis S, Okkersen K, Widomska J, Blom P, 't Hoen PAC, van Engelen B, Glennon JC. Insulin Signaling as a Key Moderator in Myotonic Dystrophy Type 1. Front Neurol. 2019;10:1229. https://doi.org/ 10.3389/fneur.2019.01229.

[102] Glozak MA, Seto E. Histone deacetylases and cancer. Oncogene. 2007;26(37):5420-32. http://dx.doi.org/10. 1038/sj.onc.1210610.

[103] Wang T, Zhang J, Xiao A, Liu W, Shang Y, An J. Melittin ameliorates CVB3-induced myocarditis via activation of the HDAC2-mediated GSK-3ß/Nrf2/ARE signaling pathway. BIOCHEM BIOPH RESCO. 2016;480(1):126-31. http://dx.doi.org/10.1016/j.bbrc.2016.09.135.

[104] Ngkelo A, Hoffmann RF, Durham AL, Marwick JA, Brandenburg SM, de Bruin HG, et al. Glycogen synthase kinase- $3 \beta$ modulation of glucocorticoid responsiveness in COPD. AM J PHYSIOL-LUNG C. 2015;309(10):L1112L1123. https://doi.org/10.1152/ajplung.00077.2015.

[105] Zhang F, Bodycombe NE, Haskell KM, Sun YL, Wang ET, Morris CA, et al. A Flow Cytometry-Based Screen Identifies MBNL1 Modulators That Rescue Splicing Defects in Myotonic Dystrophy Type I. Hum Mol Genet. 2017;26(16):3056-68. http://dx.doi.org/10.1093/hmg/ddx 190.
[106] Roskoski R. MEK1/2 dual-specificity protein kinases: Structure and regulation. Biochem Biophys Res Commun. 2012;417(1):5-10. http://dx.doi.org/10.1016/j.bbrc. 2011.11.14.

[107] Perry RL, Parker MH, Rudnicki MA. Activated MEK1 binds the nuclear MyoD transcriptional complex to repress transactivation. Mol Cell. 2001;8:291-301. http://dx.doi.org/10.1016/s1097-2765(01)00302-1.

[108] Beffy P, Del Carratore R, Masini M, Furling D, Puymirat J, Masiello P, Simili M. Altered signal transduction pathways and induction of autophagy in human myotonic dystrophy type 1 myoblasts. Int J Biochem Cell Biol. 2010;42(12):1973-83. http://dx.doi.org/10.1016/j. biocel.2010.08.010.

[109] Weg-Remers S, Ponta H, Herrlich P, König H. Regulation of alternative premRNA splicing by the ERK MAP-kinase pathway. EMBO J. 2001;20:4194-203. http:// dx.doi.org/10.1093/emboj/20.15.4194.

[110] Mankodi A, Takahashi MP, Jiang H, Beck CL, Bowers WJ, Moxley RT. Expanded CUG repeats trigger aberrant splicing of ClC-1 chloride channel pre-mRNA and hyperexcitability of skeletal muscle in myotonic dystrophy. Mol Cell. 2002;10:35-44. http://dx.doi.org/10.1016/s1097-276 5(02)00563-4.

[111] Charlet-B N, Savkur RS, Singh G, Philips AV, Grice EA, Cooper TA. Loss of the muscle-specific chloride channel in type 1 myotonic dystrophy due to misregulated alternative splicing. Mol Cell. 2002;10:45-53. http://dx.doi. org/10.1016/s1097-2765(02)00572-5.

[112] Oana K, Oma Y, Suo S, Takahashi MP, Nishino I, Takeda S, Ishiura S. Manumycin A corrects aberrant splicing of Clcn1 in myotonic dystrophy type 1 (DM1) mice. Sci Rep. 2013:3:2142. http://dx.doi.org/10.1038/srep02142.

[113] Horrigan J, Gomes TB, Snape M, Nikolenko N, McMorn A, Evans S, et al. Phase 2 Study of AMO-02 (Tideglusib) in Congenital and Childhood-Onset Myotonic Dystrophy Type 1 (DM1). Pediatr Neurol. 2020;112:84-93. http://dx. doi.org/10.1016/j.pediatrneurol.2020.08.001. Epub 2020 Aug 5. PMID: 3294208. 